\title{
An Ethical Response to Climate Change
}

\author{
Geoffrey William Lamberton \\ Southern Cross University, Australia
}

\begin{abstract}
This paper examines the ethical question of the responsibility of business organisations to respond to climate change. Ethical principles of 'polluter pays', 'historic culpability' and 'equitable distribution of the carbon budget' are applied to the question of 'should business respond to climate change', using rights and utilitarian ethical analyses. An ethical argument is established for business organisations to decarbonise their production and distribution systems rather than delay action. Government policies required to remove barriers which are delaying a widespread and meaningful response by business to humankind's greatest moral challenge together with the ethical implications are discussed.
\end{abstract}

\section{Keywords}

Rights analysis, decarbonisation, utilitarianism, carbon pricing, polluter pays principle

\section{Introduction}

Widespread agreement within the international science community supporting an immediate and extensive response to climate change has not been matched by decisive action across the broad business community (Lowe, 2010). Evidence of business-as-usual is strong and the barriers to change appear formidable (Hamilton, 2010) in spite of significant progress within the science community increasing our understanding of both climate change (Stern, 2007) and a range of feasible responses to mitigate carbon emissions (Caldeira, 2004) and adapt to expected climate change impacts.

How humankind should respond to climate change is fundamentally an ethical question requiring tradeoffs between current and future generations, allocation of resources between rich and poor nations, and value statements assessing risks enabling expected costs and benefits of alternative courses of action to be estimated and compared.

Given the primary causes of carbon emissions are energy, transport, and industrial production (accounting for $75 \%$ of anthropogenic carbon emissions), and agriculture and deforestation (accounting for the remaining $25 \%$ ) the links between business, industrialisation and climate change are apparent (IPCC, 2001; Johansen, 2007). Decisions as morally and temporally complex as climate change response represent an enormous challenge requiring globally co-ordinated solutions and given the significance of industrial emissions necessarily include business organisations in the process of change. This complexity is demonstrated by the technical difficulty of comparing the relatively low short term cost and convenience of fossil fuel based energy against the risk of increased frequency and intensity of extreme weather events, disease epidemics, famine and a degraded environment leading to loss of life, livelihood and well being (IPCC, 2007).

Climate change response is essentially a debate about sustainability. Accepted definitions of sustainability require our actions do not compromise the opportunity for future generation to meet their own needs (WCED, 
1987). If business transforms to meet the multiple goals of sustainability, this necessarily requires the elimination of reliance on non renewable resources towards reliance on non polluting, renewable energy sources (Lovins et al., 1999).

There are many possible responses the business community could make to climate change ranging from doing nothing to rapid and widespread change commencing immediately. The ethical question central to this paper is

Do business organisations have a moral responsibility to commence the decarbonisation process immediately or should they delay action in response to climate change for as long as possible?

Decarbonisation represents an important step towards transformation to the closed loop model of a sustainable business organisation which redesigns its economic production and distribution systems to enable them to be powered by renewable energy with the elimination of all waste (Lovins et al., 1999). The process of decarbonisation involves the transformation of energy, transport, mining, and agricultural systems to non fossil fuel based alternatives. Clearly the redesign of economic production and distribution systems is a long term project.

The primary ethical question offers a business-as-usual alternative which would delay any action in response to climate change until forced by legislation, or ecological constraints such as natural resource exhaustion or climate emergency. In the remainder of this paper this primary ethical question is abbreviated to should business decarbonise or delay?

\section{The ethics of climate change}

The primary ethical question is analysed using rights and utilitarian ethical theories. Rights theory is specifically relevant to climate change issues given the impact and increasing threat climate change imposes on humankind. Furthermore climate change impacts are experienced to varying degrees throughout the world and the resources available and capability to adapt vary greatly.

Utilitarian ethical theory is widely used in economic analyses (McGee, 2009) and was the method used by Stern (2007) and Garnaut (2008) in their analyses of the economics of climate change for the UK and Australian Governments. Given the significant economic cost of climate response, cost-benefit and utilitarian consequential analyses provide best guess outcomes of climate change response scenarios. The rights-based ethical analysis precedes the utilitarian analysis given a violation of rights may have consequential implications specifically in relation to financial compensation to wronged persons.

\section{Rights theory}

Deontological theories such as rights analysis require compliance with a just principle to determine morality. The ethical question critical to a rights-based approach is does an act violate someone's rights? If the answer is yes, the act is considered unethical (McGee, 2009). In the context of business and climate change the issue is whether carbon emissions by business constitute a rights violation. This rights-based analysis responds specifically to three questions

1. Has there been a rights violation?

2. If so, is there a moral case for compensation?

3. Is there a future right to emit carbon?

Answers to these questions are then linked to the primary ethical question; that is should business decarbonise or delay? 
Central to rights theory is rejection of the utilitarian idea that morality requires the pursuit of the greatest good for the greatest number in preference to the principle of never violating individual human rights (Rayner and Malone 2000, p 219). Human rights, which derive from basic moral principles such as the right to life or the right to freedom, are considered to be both universal and unconditional (Boatright, 2009).

Sterba (2009) uses a libertarian argument to prioritise the right of the poor to meet their basic needs before the rich satisfy their wants for luxury goods. Furthermore the poor have the right of non-interference; that is the rich cannot morally act in a way which interferes with the poor as they act to meet their needs. Boatright (2009, p. 37) supports Sterba's principle of the right to non interference

Rights entitle us to make claims on other people... to refrain from interfering in what we do.

The right to non interference is particularly relevant for developing countries which disproportionately carry the burden of climate change impacts (Paavola and Adger, 2002) caused by the actions of economically developed industrial nations responsible historically for the major proportion of anthropogenic climate change (Singer, 2006). Drawing on the work of Raz (1986), Caney (2005, p. 767) states that a right exists when

A person has a right to $X$ when $X$ is a fundamental interest that is weighty enough to generate obligations on others.

Caney (p. 768) then extends this principle to climate change

Persons have the human right not to suffer from the disadvantages generated by global climate change.

Disadvantages suffered by persons due to climate change include increased mortality from higher temperatures, increased frequency of weather related extreme events and resulting damage, injury and loss of life, and loss of housing due to rising sea levels (IPCC, 2007). Extensive further negative impacts from climate change are forecast with a high degree of certainty (IPCC, 2007).

Paavola and Adger (2002) draw attention to Paragraph 3 of the United Nations Framework on Climate Change (UNFCCC) Convention Article 3 which requires prevention of the causes of climate change from the duty to

...take precautionary measures that anticipate, prevent or minimise the causes of climate change and mitigate its adverse effects (UNFCCC, 1992, p. 4).

Rights-based ethical analysis supports the view that anthropogenic climate change violates the right of non interference and the right not to be disadvantaged by the actions of others which reduce the ability to meet basic needs of food, shelter, health, and security.

Attempts to shift moral responsibility from business to consumers for carbon emissions fail as many consumers lack an understanding of the complex issue of climate change and its causes, have very little influence on business production systems (Desjardins, 2007), and in many cases cannot buy alternative products produced using sustainable production systems as these products either don't exist or the information on environmental practices is ambiguous due to extensive corporate greenwash practices (Arnold and Bustos, 2005).

The moral case for compensation is supported by the polluter pays principle. Singer $(2006$, p. 2$)$ uses this principle to argue for compensation to be paid to victims by the carbon polluters

If a polluter harms others, those who are harmed normally have a legal remedy...If the rich nations pollute the atmosphere with carbon dioxide, causing my crops to fail because of changing rainfall patterns, or my fields are inundated by a rise in the sea level, shouldn't I also be able to sue? 
The polluter pays principle is evident in environmental law (Gardiner, 2010) where those that cause a problem must fix it and compensate for harm done.

Moral arguments offered against culpability for historic emissions include ignorance of impact of emissions up until climate science became widely accepted which could be interpreted as 1990 (Caney, 2005) or 2001 (Arnold and Bustos, 2005); belief that atmospheric carbon sink capacity was unlimited and therefore did not represent over use of a scarce resource; and many of those responsible for historic carbon emissions are deceased and therefore cannot be held to account for their actions (Gardiner, 2010).

In relation to a nation's responsibility for historic emissions, Gardiner asks why we would not be responsible for the costs (of burning fossil fuels) given we have inherited the benefits. By linking benefits received to historic culpability for climate impacts Gardiner, and Arnold and Bustos apply the beneficiary pays principle (Caney, 2005).

Arnold and Bustos (2005, p. 9) link the beneficiary pays principle to the culpability of business for global climate change (GCC)

Those who enjoy the benefits resulting from burning fossil fuels, and thereby contribute to GCC, ought to pay more for such benefits than those who do not enjoy such benefits.

Arnold and Bustos (2005) conclude that business organisations are morally responsible for their contribution to climate change from 2001, as this is the point where near scientific consensus was reached and communicated clearly by the IPCC. Those businesses that have not taken aggressive measure to abate....CO2 emissions (Arnold and Bustos, 2005, p 18) are negligent and responsible for the impacts of that negligence.

The rights analysis points towards a violation by business organisations emitting carbon of the right of non interference to enable people to meet basic needs. The difficulty of mounting a successful case for legal compensation for historic emissions is acknowledged. Using the polluter-pays and beneficiary-pays principles does however establish a moral case for compensation.

\section{Allocating the global carbon budget}

The third rights-based question concerns the future right to emit carbon. The capacity for the atmosphere to absorb greenhouse gases is finite. This capacity is part of the global commons and should be shared by all people and future generations (Johansen, 2007). Economically developed nations have consumed many times more than their proportional share of this scarce environmental resource and no convincing moral justification has been provided to support the expropriation of this resource to the rich.

Jamieson (2001) identifies four options for determining the future right to emit carbon

- Allocate each country equal per capita emission rights

- Allocate each country emission rights according to their historical responsibility

- Allocate emission rights according each country's ability and willingness to pay

- Some mix of the above.

These four alternatives all fit within a discourse of global managerialism which assumes as given the existence of property rights over the global atmosphere (Paavola and Adger, 2002). Caney (2005) identifies a right to emit a fair share of carbon which prima facie equates to equal per capita emission rights. Rejection of equality as an ethical position is only possible where compelling reasons are presented to support an unequal distribution. 
Gardiner (2010) uses the principle of global equity to argue for equal per capita allocation of the right to emit carbon plus carbon trading options as this would enable a transfer of wealth from rich to poor nations as rich nations purchase credits to emit above per capita national caps. Given huge national differences in current per capita emissions, an equal per capita allocation will lead to wealthy nations (who are also the largest carbon polluters) buying large amounts of unused capacity to emit carbon from the developing nations (Gardiner, 2010).

Johansen (2007) supports a staged reduction of emission levels in industrialised nations down to the global target per capita emission level over a predetermined number of years. Emission levels would converge at the agreed target date, or alternatively any emissions above agreed targets are offset by carbon trading and the transfer of funds to low emitters. Under this proposal the right to emit above an equitable level will be lost progressively up to the date of convergence.

Singer (2007) proposes a similar scheme to Johansen, adjusting the target global emission level to that required to keep the average climate increase to less than 2 degrees, and basing per capita allowances on each nation's expected total populations at the target date. This removes the incentive for nations to increase their population as a means to increasing their carbon emission allowance.

Equality in per capita emissions does not require developed nations to pay for their past use of the earth's carbon sink capacity, and is more favourable than an agreement requiring compensation for historic emissions.

Ethical justification for allocating future emission rights based on historic emission levels is difficult. Given that historic emissions represent a state of injustice, there is no credibility in repeating this (Moellendorf, 2009). Such a position requires poor developing countries to share the burden of mitigation when they do not have the financial means to so without a widespread increase in suffering within their countries. Polluter pays and ability to pay principles cannot both be ignored (McDonald, 2005).

Furthermore there should be no legal entitlement to continue historic emissions levels given the link between industrialisation, carbon emissions, climate change and climate events and therefore the violation of vital interests of other people (Johansen, 2007 p. 22).

Linking per capita emissions with individual consumption levels is an important step in empowering each global citizen to contribute to GHG emission reduction. A sense of responsibility for the emissions each of us directly causes through our consumption decisions provides an ethical motivation for change (Johansen, 2007).

However allocation is achieved, it is apparent that the right to emit should lie with nations and their citizens through an equitable allocation process. The right to emit carbon prima facie will not lie with business organisations. If business entities do not have a legal or moral right to emit carbon then they would need to acquire this right through permits or some kind of emissions trading apparatus. Many organisations operate transnationally, reflecting the need for global governance to force compliance with carbon reduction targets.

Business will be faced with two choices; purchase the right to emit carbon within globally allocated allowances and bear the cost which presumably they will pass onto consumers where possible; or transform to zero carbon emission production systems. The social, environmental and economic costs and benefits of the option to decarbonise or delay are compared in the following utilitarian analysis. 


\section{Utilitarian analysis}

The conceptual foundations of utilitarian analysis were first established in the seminal writings of Bentham (1823) and Mill (1863). Utilitarianism recognises an action as being ethical if it leads to the greatest good for the greatest number using utility as the guiding principle on which ethical decisions are based.

At the heart of consequential ethics is a rejection of the absolutist moral position central to rights analysis and other deontological ethical theories, acknowledging the moral significance of the relative context of each action; determining morality from the impact an action has on utility. John Stuart Mill argued that social utility was also the foundation for the existence of rights; and based on this principle, society is obligated to defend the possession of these rights (Thiroux and Krasemann, 2009).

The major criticism of utilitarianism is its consideration of actions that absolutists would condemn in any circumstances (Singer, 1972). However utilitarians do not accept that any means imaginable can be defended by the achievement of a just goal. Questioning the unquestionableness of an absolute position is not in itself immoral, but rather reflects the grim reality that sometimes we are forced to choose the lesser of evils, and selecting the alternative which minimises harm may be the moral course of action (Nielson, 1972).

It is feasible that a utilitarian view of climate change may recognise the only options available involve minimising negative impacts, acknowledging that all policy directions involve some level of harm to people and the ecological systems which support them.

Utilitarian analysis has been used in the context of climate change with both Stern (2007) and Garnaut (2008) opting for its economic derivative cost-benefit analysis to formulate their recommended ethical and economic responses to the challenge of climate change in their reports to the UK and Australian Governments. Stern and Garnaut used cost-benefit analysis to conclude action should be taken immediately to reduce the cost of dealing with a greater problem, as delaying action was seen to increase risk of extreme climate events as well as the costs of adaptation and mitigation.

Cost benefit analysis must be interpreted carefully in full recognition that economic valuation of social and environmental costs and benefits is not precise. For example users of cost-benefit data must understand the extreme difficulty of estimating the cost of the loss of life, or the benefit of avoiding the extinction of a species (Singer, 2002).

An assumption which underpins cost-benefit analysis is that where there is a net positive benefit a transfer can occur to ensure an equitable solution for both winners and losers (Howarth, 2000). This is extremely difficult to achieve over intergenerational time scales making it difficult to achieve the goal of an equitable distribution of climate related positive and negative consequences between generations.

Utilitarians use utility (or welfare) rather than money as the unit of account on which social decisions should be made. Table 1 provides a utilitarian comparison of the business decision to decarbonise or delay action on climate change across 12 decision criteria. The main consequences are identified for each decision criteria and discussed following the table. 
Table 1 Utilitarian decision analysis

\begin{tabular}{|c|c|c|}
\hline \multirow[t]{2}{*}{ Decision criteria } & \multicolumn{2}{|c|}{ Consequences } \\
\hline & Decarbonise & Delay action \\
\hline \multicolumn{3}{|l|}{ Economic } \\
\hline Cost & Cost of immediate decarbonisation & $\begin{array}{l}\text { Future cost of decarbonisation and } \\
\text { increased anthropogenic impact on } \\
\text { climate }\end{array}$ \\
\hline Efficiency & Natural resource conservation & Low short term energy cost \\
\hline Energy supply & Insufficient infrastructure & Fossil fuel reserves \\
\hline Legal & Historic culpability for emissions & Historic and future culpability \\
\hline \multicolumn{3}{|l|}{ Socio-political } \\
\hline Social & Health impact of fossil fuels & Maximise material wealth in short term \\
\hline Political & $\begin{array}{l}\text { Negative consumer reaction to } \\
\text { higher prices }\end{array}$ & $\begin{array}{l}\text { Pressure from consumer and } \\
\text { environmental organisations }\end{array}$ \\
\hline \multicolumn{3}{|l|}{ Climate risk } \\
\hline Environmental & $\begin{array}{l}\text { Reduce carbon pollution and } \\
\text { anthropogenic impact on climate }\end{array}$ & Manage each climate event $\&$ adapt \\
\hline Risk management & Precautionary principle & Climate science inexact \\
\hline \multicolumn{3}{|l|}{ Organisational } \\
\hline Strategy & First mover advantage & Business as usual \\
\hline Managerial & Implement change incrementally & $\begin{array}{l}\text { Allocate managerial resources to non } \\
\text { carbon projects }\end{array}$ \\
\hline Leadership & $\begin{array}{l}\text { Increase momentum for global } \\
\text { change }\end{array}$ & Prisoner's dilemma \\
\hline Sustainability & $\begin{array}{l}\text { Convergence of long term business } \\
\text { viability with sustainability }\end{array}$ & $\begin{array}{l}\text { Environmental benefits traded off against } \\
\text { economic benefits }\end{array}$ \\
\hline
\end{tabular}

\section{Economic}

Economics is central to the decision taken by many business organisations to delay response to climate change. All of the criteria in Table 1 have economic implications however the first four decision criteria are fundamental to the economics of climate response. 
Nordhaus (2007) suggests immediate reductions in carbon emissions will cost more than their expected benefits, an argument supported by Lomborg (2001). However both Stern (2006) and Garnaut (2008) take a different view suggesting action now will cost less than delaying and taking action later. The different conclusion is explained mostly by their choices of discount rates. Nordhaus bases his choice of discount rate on prevailing money market interest rates. Stern and Garnaut use extremely low discount rates thereby valuing the rights of generations almost equally over time.

Their approach is consistent with the utilitarian rule which places equal weight on the welfare of every individual, including those yet to be born, whilst considering the economic practice of discounting inequitable from an intergenerational perspective. Parfit (1983, p. 31) argues

...the moral importance of future events does not decline at $n$ percent per year. A mere difference in timing is in itself morally neutral.

The discount rate would take on more relevance if impacts of climate change were purely economic. However many of the projected consequences of climate change concern life or death, poverty and starvation, the inequitable distribution of the benefits from burning fossil fuels compared to the harm caused, the plight of environmental refugees, the long term viability of humankind and other species. Such extreme consequences cannot morally be considered irrelevant no matter how far in the future they are projected to occur.

Decarbonisation is part of an overall efficiency strategy focusing on the sustainable use of natural resources by business. Central to the goal of sustainable business is the design of closed loop economic systems where waste is eliminated with production and distribution systems powered from sustainable and renewable energy sources (Lovins, et al 1999; McDonough and Braungart, 2002).

The sustainable business strategy is promoted as a way of using natural resource inputs more efficiently to generate increased economic returns (Lovins, et al 1999). Some scepticism is appropriate (Trainer, 2000) given the cost of building the infrastructure for a decarbonised economy including zero emission transport, renewable energy generation, and the redesign of economic production systems would be significant.

However it should be acknowledged that the alternative delay strategy which prioritises the utilisation of low economic cost energy sourced from fossil fuels is only available as a cheap option given the environmental and social costs (of pollution, ecosystem degradation and human health impacts etc.) are externalised and excluded from prices. Whilst there may be an incentive in the short term to externalise costs by polluting the global commons, there is no long term economic rationale in destroying the ecological systems that enable the economy to exist.

The third decision criteria in Table 1 (supply of energy) provides an additional strong motivation for business to delay action due to the ready availability of fossil fuel generated energy; whereas low to zero carbon energy supply requires large scale investment in infrastructure. This needs to be balanced against the reducing supply of non renewable resources which appears to be a medium term problem for oil and gas, and a longer term problem for coal (Bardi, 2009; Shafiee and Topal, 2009).

Critical to a consequential analysis of climate change response by business, is the potential liability for environmental and social impacts caused by carbon emissions. Neumayer (2000) argues strongly for historic culpability of nation states for carbon emissions based on the strength and widespread acceptance of climate science; the polluter pays principle; and equality of opportunity to use the global atmospheric commons, as those that pollute it or overuse it will be forced to pay compensation to those harmed by these actions. 
The rights based analysis provides an ethical argument for climate change response to include both mitigation and adaptation financed by the large historic polluters. From what point this responsibility is activated is controversial. Regardless of culpability for historic emissions, culpability for future carbon emissions can be avoided by decarbonisation.

\section{Socio-political}

Social consequences of the decision to decarbonise or delay action match the benefits of reducing the negative health impacts of burning fossil fuels against the socio-economic benefits of prioritising economic growth in the short term. Delaying decarbonisation allows business to produce more goods and services leading to the material benefits that follow from lower priced consumer goods. The physical and psychological health problems caused by excess consumption of consumer goods (Hamilton and Denniss 2005) reduce some of the benefits of higher production.

Haines et al. (2006) report the impact of increasingly regular and severe weather events causing death and destruction in Europe and the USA, as well as increased likelihood of infection from vector-borne diseases. They conclude the major effect of climate change on human health will be felt in developing countries and within more vulnerable groups (the elderly, poor and very young) in developed countries. Additional negative occupational health and safety consequences from mining coal, oil and gas should also be factored in to the analysis.

Organisations which decarbonise and pass increased energy costs through to consumers may encounter strong negative reaction against higher prices; or alternatively environmental organisations and environmentally motivated consumer groups may apply political pressure for change to those companies which continue business as usual. In either case this may lead to consumer boycotts and/or loss of market standing.

\section{Climate risk}

The environmental benefits of decarbonisation involve the reduced contribution of humankind's fossil fuel based economy to climate change. Carbon is not the only pollution problem caused by the combustion of fossil fuels. Emissions of sulphur dioxide, nitrous oxide, carbon monoxide, and heavy metals such as lead, cadmium and mercury are all released into the air from fossil fuel combustion (Olivier and Berdowski, 2001).

Delaying action would enable more resources in the short term for adaptation and managing climate events as they occur. However decarbonisation reduces the risk of climate change and is consistent with the precautionary principle; that is

...the commitment of resources now to safeguard against the potentially adverse future outcomes of some decision (Perrings, 1991).

A risk-based argument for delaying action is that climate response can be taken further in the future when knowledge of climate change and effective solutions are better understood, avoiding taking action now which may have unintended and negative consequences or prove to be unnecessary. However this argument is contrary to the increasing climate threat reported by the IPCC (Smith et al., 2009).

\section{Organisational}

The strategic consequence of delaying action is to enable business-as-usual for as long as legally or ecologically possible. However the business-as-usual strategy forfeits potential benefits from being an early adopter of low and zero carbon technologies. These potential first mover benefits include access to the green market segment and the longer term benefits of having the company's brand associated with climate solutions. 
Gardiner (2010, p 61) challenges resistance to carbon mitigation by business

...it would be easier for economic institutions to cope with sensibly managed regulation than with specific climate impacts, since the former could be designed to be gradual, predictable, and incremental, whereas the latter are likely to be sudden, unpredictable, and potentially large-scale.

The managerial divide between the decarbonise or delay options reflect the proactive decarbonisation agenda where management determine the timetable and process of change versus delayed action to reduce carbon emissions in response to legislation or natural constraints. Less time and opportunity for effectively managing and implementing change exists under the delayed response option.

Ultimately a global solution is required to eliminate as much as possible the human caused component of climate change. The leadership strategy that maximises the possibility of a global solution is to demonstrate the viability of zero or low carbon economic production models. Currently most economic actors are standing back waiting for someone else to move. This standoff increases the cost of future action, hastens climate change and encourages other actors to delay their response.

Gardiner (2006) describes this standoff as a Prisoner's dilemma involving a natural resource. The dilemma is due to the paradox that collectively all agents are better off if they restrict carbon pollution but individually it is rational to externalise the immediate cost of pollution and benefit from the cheap short term supply of fossil fuels. By acting rationally from an individual perspective, business organisations undermine their own long term viability and are thus caught within a tragedy of the commons scenario (Hardin 1968).

Organisations which choose to decarbonise will recognise the link between their long term economic viability and the need to redesign economic systems to be compatible with the preservation of the ecological systems which enable human and economic development. Organisations which delay will believe there is a trade off between environmental gains and economic gains, continuing to prioritise economic goals. However in the long term, economic viability is only feasible within an economy designed for sustainability, otherwise it is inherently self destructive.

\section{Conclusions from ethical analysis}

The preceding rights analysis concludes there is a right to non interference where interference causes suffering from the impacts of climate change. Where this right is violated moral grounds for compensation are supported by the polluter pays principle and beneficiary pays principle. Business organisations as major contributors to and beneficiaries from anthropogenic climate change have a moral obligation to aggressively reduce carbon emissions, or else risk claims for compensation from those whose rights they violate.

Various scenarios to allocate the carbon budget were explored. The future right to emit carbon would logically lie with nations and their citizens, and under this scenario business would need to purchase the right to emit carbon. The most morally convincing climate solution defines an equal per capita right to emit carbon at an agreed target date. At that time national per capita emission rates converge, or nations above the per capita allowance purchase unused quota from nations below the per capita allowance, enabling the global carbon emission target to be met.

The utilitarian analysis identifies two influential reasons for business to delay action; these are the short term economic benefits of exploiting low cost fossil fuels and ready availability of fossil fuel reserves and energy infrastructure.

The most significant positive consequences for decarbonisation are the - 
- Potential strategic and financial first mover benefits

- Avoidance of future liability for climate change damages

- Resource conservation and efficiency benefits of adopting the natural capitalism sustainable business model

- Social and environmental health benefits of reducing pollution

- Managerial benefits of managing change incrementally rather than reactively in response to a climate emergency or Government imposed regulations.

The major economic benefit for organisations to delay action needs to be assessed in the light of the reports by economists Nicholas Stern and Ross Garnaut. In both reports the conclusion is that the economic cost to society rises with delay. If this is correct the business decision to delay action does not lead to an optimal economic outcome for society as a whole and fails the utilitarian rule of the greatest good for the greatest number.

This emphasises the need for Governments to align business decision making which is usually focused on achieving self interest short term goals with the longer term well being of society and future generations. A range of policy responses aimed at encouraging business to meet their moral responsibility to decarbonise their production systems and relevant ethical issues are considered in the next section of this paper.

\section{The ethics of climate policy}

Stern (2007) identifies the three essential elements of government climate change policy as carbon pricing, technology development and the promotion of behavioural change. These options together with major ethical implications are discussed in this section.

Carbon pricing can be used as a mechanism to include the cost of carbon emissions in market prices of goods and services. The difficulties of calculating the social cost of carbon pollution (i.e. the estimated cost of the damage caused by each additional unit of carbon emitted) are well accepted (Hope and Newbery, 2007). Various economic models are available which provide estimates of the economic damage of carbon pollution; however these models must be viewed as best guesses rather than precise measurements (Pearce, 2003). Uncertainty in calculating the actual cost of carbon increases the difficulty for policy makers when designing carbon pricing systems, as there will be considerable political pressures to implement a high or low carbon price depending on the values and vested interests concerned (Griffiths et al., 2007).

Imposing a carbon tax on business organisations which emit carbon represents an application of the polluter pays principle. Earlier in this paper this principle was used to support the moral case for compensation to those whose rights have been violated by the effects of carbon pollution. However carbon pricing whether implemented using a carbon tax or emissions trading scheme, requires the cost of pollution to be paid up front by the polluter. Typically the cost of carbon paid by the polluter is passed on to consumers through market prices. Due to the regressive nature of the tax, there is a social case for tax revenue collected to be used to compensate low income earners who can least afford the extra cost.

Emissions trading schemes provide another means of aligning business and societal goals through imputation of a carbon price. An ethical argument against 'cap and trade' carbon schemes is the concern they create a property right over the atmosphere enabling carbon emission into the global commons.

In response to this concern some licences to emit carbon are defined so as not to be construed as a property right (for example the US Regional Greenhouse Gas Initiative trading scheme); but rather as temporary agreements enabling the licence (or permit) to emit carbon to be removed at any time without compensation (Hamilton and Muller, 2007). 
Linking domestic carbon markets to create an international carbon market where carbon permits and credits are traded would facilitate a flow of investor funds from richer to poorer nations to fund clean energy development in developing nations. However transfers must be authentic and lead to increased welfare in poorer nations. An ethical problem with emissions trading is the capital inflows into poorer countries may not benefit the poor but rather be siphoned off by corrupt officials (Singer 2002); thus making transparent control and audit mechanisms to avoid potential corruption essential.

Emission trading schemes usually allow for some level of carbon offsetting using approved carbon credit schemes (see for example the Kyoto Clean Development Mechanism). Carbon offsets although controversial in nature (He and Morse, 2010) provide scope for an ethical response whereby carbon polluters provide funds to construct renewable energy infrastructure in developing countries. Potentially this can achieve the environmental goal of reducing global carbon pollution at the same time as the social goal of reducing poverty, by providing developing countries with economic infrastructure powered by renewable energy.

The intended outcome of carbon pricing schemes is to stimulate the transition to clean, renewable energy alternatives; although there is no clear evidence from countries such as Norway, Denmark and Sweden that have had high carbon prices for many years that a carbon price will be successful in achieving this outcome (Bruvoll and Larsen, 2004). The success of the carbon price in creating change to renewable energy depends on the level of the carbon price and the responsiveness of demand for carbon intensive goods and services to price increases. Bunn and Fezzi (2007) found a strong relationship between changes in the carbon price under the EU Emissions Trading Scheme and electricity prices in the UK, suggesting a direct relationship does exist.

A major ethical issue for Government relates to how the revenue they collect from carbon pricing schemes is distributed. Possible uses of carbon tax revenue include

- Technology research and development: this includes clean and renewable energy options; technologies to increase carbon sink capacity; carbon sequestration; and zero emission transport systems.

- Build renewable energy infrastructure (such as electricity generation plants and electric vehicle recharge stations).

- Reduce deforestation (for example farmers could be paid to maintain rather than destroy forests on land they occupy).

- Compensate low income households (as already discussed to offset the effect of carbon prices being passed onto consumers).

- Buy off political opponents to climate change legislation (which may include large energy suppliers, large emitters of carbon and companies in the fossil fuel industries).

- Fund climate change adaptation in both economically developed and developing countries.

Compensation to polluting industries is difficult to support ethically and appears to be a political act to reduce opposition to the policy. However tax proceeds paid to polluters could be tied to clean energy research and development and employee assistance and retraining programs, as workers are required to shift out of fossil fuel industries into the renewable energy sector.

As climate change is inevitable, adaptation measures are also required. Given the high carbon emitting nations are also the world's wealthiest nations, requiring these nations to give up some of their wealth to fix this problem would lead to less reductions in benefits than if developing nations are asked to share or carry the burden of financing the solution (Singer, 2002). 
Developing countries are looking to the historically high carbon emitting and wealthier countries to lead and fund the transition to low carbon economic production given their ability to pay and moral culpability in contributing to anthropogenic global warming. Potential climate adaptation programs are vast and include for example heat wave management, water and cooling systems, more climate robust farming methods, energy and climate efficient housing.

The third component of Government climate policy is to promote behavioural change to reduce both waste and unnecessary consumption. Policy options include

- Removing incentives and subsidies to pollute (refer Reidy, 2007 for a detailed list).

- Penalising waste at point of consumption (this can be achieved by increasing prices for consumer goods by carbon pricing).

- Education and information dissemination regarding energy efficiency (for example smart travel, insulation, efficient lighting and appliance options; Stern, 2006).

Behavioural change is considered the quickest and most cost effective way of reducing carbon emissions. However the success of these programs may be tied to the long term process of changing values whereby energy is seen to be a scarce natural resource where consumption is limited by a strong conservation ethic, emphasising the educational and long term dimensions of climate change policy.

\section{Conclusions}

Business has a deontological responsibility to stop contributing to anthropogenic climate change which violates the right of non interference to meet human needs and a utilitarian obligation to assist the transition to a low carbon economy as this is consistent with the greater good. This moral conclusion is consistent with an immediate business strategy to decarbonise its economic production and distribution systems and cooperate with Government which needs to implement a broad range of policies including carbon pricing, technology development and the promotion of behavioural change to encourage the transition to sustainable business to take place.

\section{References}

Arnold, D. G. and Bustos, K. 2005. Business, Ethics and Global Climate Change, Business \& Professional Ethics Journal, 24 (1 \& 2)1-27.

Bardi, U. 2009. Peak Oil the Four Stages of a New Idea, Energy, 34 (3) 323-326.

Bentham, J. 1823. An Introduction to the Principles of Morals and Legislation. W. Pickering, London.

Boatright, J. R. 2009. Ethics and the Conduct of Business. Pearson, New Jersey.

Bruvoll, A. and Larsen, B. 2004. Greenhouse gas emissions in Norway: do carbon taxes work? Energy Policy, 32. 493-505.

Bunn, D. and Fezzi, C. (2007). Interaction of European Carbon Trading and Energy Prices, Fondazione Eni Enrico Mattei Working Paper 123, http://www.bepress.com/feem/paper123.

Caldeira, K., Morgan, M., Baldocchi, D., Brewer, P., Chen, C., Nabuurs, G., Nakicenovic, N. and Robertson, G. 2004. A portfolio of carbon management options, in C. Field and M. Raupach (eds.). The global carbon cycle (Island Press, Washington, DC, 103-130).

Caney, S. 2005. Cosmopolitan Justice, Responsibility, and Global Climate Change, Leiden Journal of International Law, 18747-775.

DesJardins, J. 2007. Business, Ethics, and the Environment Imagining a Sustainable Future. Pearson, New Jersey. 
Gardiner, S.M. 2006. A Perfect Moral Storm Climate Change, Intergenerational Ethics and the Problem of Moral Corruption. Environmental Values, 15(3). 397-413.

Gardiner, S. M. 2010. Ethics and Climate Change An Introduction, WIREs Climate Change, 1 (Jan/Feb) 5466. doi 10.1002/wcc.016.

Garnaut, R. 2008. The Garnaut Climate Change Review. Cambridge University Press.

Griffiths A., Haigh, N.and Rassias, J., 2007. A Framework for Understanding Institutional Governance Systems and Climate Change: The Case of Australia. European Management Journal, 25(6). 415-427.

Haines, A., Kovats, R.S., Campbell-Lendrum, D. and Corvalan, C. 2006. Climate Change and Human Health Impacts, Vulnerability, and Mitigation, Lancet 3672101-2109.

Hamilton, C. and Denniss, R., 2005. Affluenza When Too Much is Never Enough. Allen \& Unwin, Sydney.

Hamilton, C. 2010. Requiem for a Species. Allen \& Unwin, Sydney.

Hamilton, C. and Muller, F. 2007. Critique of the McKibbin-Wilcoxen Hybrid Emissions Trading Scheme, Research Paper No. 42, Australia Institute, March.

Hardin, G. 1968. The Tragedy of the Commons, Science, 1621243-1248.

He, G. and Morse, R. (2010). Making Carbon Offsets Work in the Developing World: Lessons from the Chinese Wind Controversy, March 12. Available at SSRN: $\underline{\text { http://ssrn.com/abstract=1583616 . }}$.

Hope, C. and Newbery, D. 2007. Calculating the social cost of carbon. Faculty of Economics, University of Cambridge, UK.

Howarth, R, B. 2000. Normative Criteria for Climate Change Policy Analysis, Redefining Progress, February, $1-29$.

IPCC 2001. Climate change 2001 the scientific basis. Intergovernmental Panel on Climate Change, Cambridge University Press.

IPCC 2007. Climate Change 2007 Synthesis Report. Intergovernmental Panel on Climate Change, Geneva.

Jamieson, D. 2001. Climate Change and Global Environmental Justice, in Miller, C. A. \& Edwards, P. N. (eds.), Changing the Atmosphere Expert Knowledge and Environmental Changing the Atmosphere Expert Knowledge and Environmental Governance, MIT Press, Cambridge, 287-307.

Johansen, I. 2007. Exploring the Principle of Equal Emission Rights, Ethics of Climate Change, Norwegian Academy of Technological Sciences, 1-53.

Lomborg, B. 2001. The Skeptical Environmentalist, Cambridge University Press.

Lovins A., Lovins L. H. and Hawken P. 1999. Road Map for Natural Capitalism. Harvard Business Review. May-June.145-158.

Lowe, I. 2010. The limits of Growth Revisited, In Goodbye to All That? On the Failure of Neoliberalism and the Urgency of Change. McKnight, D. and Manne, R (eds) Black Inc. 207-229.

McDonald, M. 2005. Fair Weather Friend? Ethics and Australia's Approach to Global Climate Change, Australian Journal of Politics and History, 51(2). 216-234.

McDonough, W. and Braungart, M. 2002. Cradle to Cradle Remaking the Way We Make Things. North Point, New York.

McGee, R.W. 2009. Analyzing Insider Trading from the Perspectives of Utilitarian Ethics and Rights Theory, Journal of Business Ethics. 9165-82. doi10.1007/s10551-009-0068-2.

Mill, J. S. 1863. Utilitarianism. Parker, Son, and Bourn, London.

Moellendorf, D. 2009. Treaty Norms and Climate Change Mitigation, Carnegie Council for Ethics in International Affairs. 247-265.

Neumayer, E. 2000. In Defence of Historical Accountability for Greenhouse Gas Emissions. Ecological Economics, 33185-192.

Nielson, K. 1972. Traditional Morality and Utilitarianism. Ethics, 82113-124.

Nordhaus, W.D. 2007. A Review of the Stern Review on the Economic of Climate Change. Journal of Economic Literature, XLV (September). 686-702. 
Olivier J., and Berdowski, J.2001. Global Emission Sources and Sinks, in Climate System Berdowski et al. (eds.). Swete \& Zeitlinger, Lisse.

Paavola, J., and Adger, W. N. 2002. Justice and Adaptation to Climate Change. Tyndall Centre for Climate Change Research, Working Paper 23, October.

Parfitt, D. 1983. Energy Policy and the Further Future The Social Discount Rate, in Energy and the Future, D. MacLean and P. G. Brown (eds.). Totowa, New Jersey, Rowman and Littlefield.

Pearce, D. 2003. The social cost of carbon and its policy implications. Oxford Review of Economic Policy, 19(3). 362-384.

Perrings, C. 1991. Reserved Rationality and the Precautionary Principle Technological Change, Time, and Uncertainty in Environmental Decision Making, in Ecological Economics The Science and Management of Sustainability, (ed.) R. C. Costanza. New York, Columbia University Press.

Rayner, S., \& Malone, E. L. 2000. Climate Change, Poverty and Intragenerational Equity the National Level, in Munasinghe, M. \& Swart, R. (eds). Climate Change and its Linkages with Development, Equity and Sustainability. Intergovernmental Panel on Climate Change, Geneva. 215-242.

Raz, J. 1986. The Morality of Freedom. Oxford University Press, Oxford, UK.

Riedy, C. 2007. Energy and transport subsidies in Australia, Final Report, Institute for Sustainable Futures, UTS, Australia.

Shafiee, S. \& Topal, E. 2009. When Will Fossil Fuel Reserves be Diminished? Energy Policy, 37 (1). 181189.

Singer, P. 1972. Is Act-Utilitarianism Self-Defeating? The Philosophical Review 81 (1). 94-104.

Singer, P. 2002. One World The Ethics of Globalization. New Haven Yale University Press.

Singer, P. 2006. Will the Polluters Pay for Climate Change? Project Syndicate, August 12.

Singer, P. 2007. A Fair Deal on Climate Change? Project Syndicate, June 26.

Smith, J.B., Schneider, S. et al. 2009. Assessing dangerous climate change through an update of the Intergovernmental Panel on Climate Change (IPCC) "reasons for concern", PNAS 106 (11) March 17 4133-4137. doi 10.1073/pnas.0812355106.

Sterba, J. P. 2009. Our Basic Human Right is a Right to Liberty and it Leads to Equality, in Ethics, the big questions ( $2^{\text {nd }}$ ed.) Sterba J. P. (ed). Wiley-Blackwell. 285-295.

Stern, N. 2006. What is the Economics of Climate Change? World Economics, April-June, 7(2). 1-10.

Stern, N. H. 2007. The Economics of Climate Change. Cambridge University Press, UK.

Thiroux, J.P., \& Krasemann, K.W. 2009. Ethics Theory and Practice $\left(10^{\text {th }}\right.$ ed). Pearson, New Jersey.

Trainer, T. 2000. The Simpler Way, viewed 28 August 2010 at http//ssis.arts.unsw.edu.au/tsw/ .

UNFCCC. 2002. United Nations Framework on Climate Change. United Nations.

WCED, 1987. Our Common Future. Oxford University Press, Oxford, UK. 
